\title{
Por uma escola Que ATENDA AS NECESSIDAdes ESPECIAIS DE SEUS AlUNOS
}

Eliane Tie Mi IMAMURA ${ }^{1}$

BEYER, Hugo Otto. Inclusão e avaliação na escola: de alunos com necessidades educacionais especiais. Porto Alegre: Mediação, 2005, 128p.

A partir de projetos como o programa do governo federal de Educação para todos e do processo de inclusão de crianças com deficiência no sistema regular de ensino, surge a preocupação de revisar os papéis que a educação especial e a escola regular passam a desempenhar frente a essa realidade.

Visto que os paradigmas constituem formas sociais e culturais de representar ou entender a pessoa que apresenta limitações funcionais, o autor perpassa pelos paradigmas que fundamentaram a educação especial, uma vez que estes inferem diretamente no modo como é oferecido o atendimento pedagógico a essa população.

Assim, o livro assinala a importância histórica da educação especial, faz menção de que o ensino especial não seja extinto, mas que seu atendimento seja modificado diante da proposta inclusiva. O papel do professor especializado, nesse sentido, se dá em parceria com professor da escola regular para atender as necessidades e potencialidades peculiares, de cada aluno, dentro do ensino regular.

A proposta de educação desenvolvida no livro é que o ensino necessita ser individualizado, não no atendimento, mas na elaboração dos objetivos, da didática e do processo de avaliação. Nesse âmbito, as ações pedagógicas podem e devem ser desenvolvidas no contexto de sala de aula.

Podem ser verificados, com a apresentação da experiência inclusiva alemã, procedimentos que inferem na prática do ensino inclusivo efetivo, tais como: embasamento político-pedagógico, suporte para o professor, quantidade de alunos por sala, envolvimento de todos os sujeitos. Procedimentos estes que podem nortear o processo de educação brasileiro.

O enfoque do livro sobre a avaliação de pessoas com necessidades especiais não tem o intuito classificatório, mas inspira-se na teoria da zona de desenvolvimento real e proximal de Vygotsky, no sentido de verificar não apenas

\footnotetext{
${ }^{1}$ Mestranda do programa de Pós-graduação em Educação da Faculdade de Filosofia e Ciências da Unesp campus de Marília - elianeimamura@yahoo.com.br 
as condições atuais do desempenho escolar da criança, mas as habilidades que estão emergentes. Nesse sentido, salienta que se faz necessário contextualizar o ambiente sócio-afetivo da criança.

A avaliação, assim, serve para favorecer o processo de inclusão no sentido de oferecer dados que informem a necessidade de apoio e de todas as variáveis que inferem no processo de ensino-aprendizagem.

Por fim, o livro apóia-se na abordagem vygotskiana e na abordagem de Feuerstein e elucida novos rumos para a prática pedagógica por meio do procedimento de ensino mediado, que leva em consideração os variados aspectos do desenvolvimento e das vivências sociais dos alunos.

A leitura do livro pode propiciar uma reflexão sobre o longo caminho que ainda necessita ser percorrido, pelos alunos, familiares, professores, direção, funcionários e gestores políticos para a efetivação da proposta inclusiva, mas também lança um olhar de esperança sobre um futuro possível no qual a educação seja finalmente para todos. 